\title{
文章の特徴量を用いた質問回答文の印象の因子得点の推定
}

\author{
横山 友也*, 宝珍 輝尚*, 野宮 浩揮*, 佐藤 哲司** \\ * 京都工芸䋊維大学大学院工芸科学研究科, ** 筑波大学図書館情報メディア系
}

\section{Estimation of Factor Scores of Impression of Question and Answer Statements by Using Feature Values of Statements}

\author{
Yuya YOKOYAMA*, Teruhisa HOCHIN*, Hiroki NOMIYA* and Tetsuji SATOH** \\ * Graduate School of Information Science, Kyoto Institute of Technology, Gosyokaidou-cho, Matsugasaki, Sakyo-ku, Kyoto 606-8585, Japan \\ ** Faculty of Library, Information and Media Science, University of Tsukuba, 1-2 Kasuga, Tsukuba-shi, Ibaraki 305-8550, Japan
}

\begin{abstract}
In order to avoid the problem of mismatch between the questioner and the respondent at Q \& A sites, we have experimentally evaluated the impression of 60 question and answer statements posted at Yahoo! Chiebukuro by using 50 impression words. Nine factors as to statements have been obtained by applying the factor analysis to the scores obtained through the experiment. Factor scores of any other statements have been tried to be estimated by using multiple regression analysis. This paper tries to estimate those factor scores through the multiple regression analysis by adopting such feature values as syntactic information, word imageability and closing sentence expressions. As a result, estimation accuracy for every factor is overall well and drastically improved by focusing on closing sentence expressions as well as syntactic information and word imageability. The validity of estimation is also confirmed by inspecting important feature values.
\end{abstract}

Keywords : Question \& Answer statement, factor score, multiple regression analysis

\section{1.はじめに}

インターネット上における質問回答サイトの利用者が近年 急増している.質問回答サイトとは, インターネット上でユー ザ同士が互いに質問と回答を投稿しあうコミュニティの一形 態であり，様々な悩み事・相談事を解決する場であると同時 に, 膨大な知識が蓄積されたデータベースとして活用される ようになってきている [1]，あるユーザが質問を投稿する と，他のユーザがその質問に対して回答を投稿する。質問者 は，質問文に対して最も適切と判断した回答文を「ベストア ンサー」に選定し，その回答を行った回答者に謝礼として手 持ちのポイントを贈与する.ここで,「ベストアンサー」とは, 質問文に対する満足度が最も高いと質問者が主観的に判断し た回答文である。

質問回答サイトの参加者が増え, また, 投稿される質問数 が膨大になると, 回答者が自身の専門性や興味に合った適切 な質問文を探し出すことが困難になるという問題が顕在化し てくる，あるユーザが質問文を投稿しても，その質問文が必 ずしも適切な回答者の目に留まり, 回答を得られるわけでは ないという問題である。また，適切な回答者に巡り会えない ミスマッチから，質問者にも不利益も生じる。つまり，質問 回答サイトの課題は, 日々投稿され続けている幾多の質問 と, 様々な興味·関心や専門性を有する回答者とを適切にマッ チングすることであるが，質問者や回答者の努力に任せてい るのが現状である。 そこで，ある質問文に適切な回答ができ
るユーザをその質問文に引き合わせるための方法が研究され ている [2-11].

これまでの研究において, 筆者らは, 質問者に適切な回 答者を引き合わせるために, 質問者と回答者の相性を判断 する手段として質問者と回答者の文章の印象評価を行って きた [2]. Yahoo! 知恵袋 [1]に投稿された質問文と回答文 の計 60 個の文章に対して, 50個の印象語を使用して, 印象 評価を行った. 得られた評価值に対して因子分析を行った結 果, 文章内容に関する因子が9個得られた。また, 得られた 因子の因子得点を適宜利用することで，「ベストアンサー」 を特定できる可能性を示した [2]. しかし，ここで得られた 因子得点は, 評価実験を行った質問文と回答文の文章 60 個 に対するもののみであって, 他の多数の質問文と回答文に対 する因子得点は得られていない.

そこで，本論文では，どのような回答文に対しても「べス トアンサー」の推定を可能にすることを目的として, 文章の 特徵量からの文章の因子得点の推定を試みる。ここでは, 重 回帰分析を使用して, 文章の特徴量から因子得点を推定す る.ここでは, 名詞や動詞などの品詞, ひらがな, カタカナ, 英数字の出現回数あるいは比率など, 形態素解析を使用して 求められるものを文章の特徵量として採用する [3]. また, 単語心像性も採用する。単語心像性とは, 単語から喚起され る様々なイメージが, どの程度思い浮かべやすいかを示す主 観的特性である.さらに, 文末表現 [4]も追加する。これ らの特徴量を用いて因子得点を推定すると, 全ての因子につ いて精度良く因子得点が推定できることを示す。 
以降，2.では関連研究について述べ，3.では質問回答文に 対する印象評価実験とその結果得られた9個の因子について 述べる. 4. では文章の特徴量とそれを用いた因子得点の推定 について述べる. そして, 5. で推定結果を評価し, 6. で推定 結果の妥当性を確認する。最後に7.でまとめる.

\section{2. 関連研究}

これまでに,「ベストアンサー」を推定する研究が行われ てきている [4-11]. Bloomaらは, 非テキスト特徴量とテ キスト特徴量を用いて,「ベストアンサー」の推定を試みて いる [5]. Agichteinらは, 内容や語法の特徵量を使用するこ とによって，質問文と回答文の質の評価を試みている $[6]$. また, 類推による手法も提案されてきている [7]. この手法 では，過去の知見における質問文と回答文のリンクを使用す ることによって,「ベストアンサー」を探索する，Kimらは， 「ベストアンサー」の選択基準を提案している [8]. 情報型 の質問は, 文章内容の特徵量が重要であり, 提案型の質問に は有用性が重要であり, 選択型の質問には社会的な感情が重 要であるとしている.

西原らは, ある 1 つの質問文に対する回答文群より,「べス トアンサー」になりやすいものを検出する手法を提案してい る [4]. 質問者と回答者の文末表現の相性に着目し, 質問文 と「ベストアンサー」の組み合わせをクラスタリングするこ とで, 一定の成果をあげている。しかし, この研究では質問 文ならびに回答文の文末表現に着目した手法をとっており, 文章内容に着目した手法をとっていない，そこで, 本研究で は, 文末表現も特徵量として考慮した上で, 文章全体の文体 や内容加受ける印象評価に着目して検討を行う。

一方, 熊本は新聞記事を対象として印象評価を行ってい る [12]. 利用者 100 人が 10 本の新聞記事を読み, 印象語 42 語のそれぞれについて 5 段階（強い一わりと強い一わりと 弱い一弱い一なし) で評価するという印象評価実験を 9 度実 施し, 印象評価デー夕（印象語 42 語 $\times 9,000$ 件）を収集 · 分析することによって, 新聞記事の印象を表現するのに適し た印象軸を提案している [12]，本研究では，質問回答文を 対象として，印象語を用いた印象評価実験を行う。

\section{3. 印象評価実験}

本章では, 因子得点の推定の基盤となる9個の因子を抽出 した評価実験 [2]の概要を述べる。

\section{1 印象 語}

印象語とは, 文章を評価するにあたって, その文体や内容 から受けた印象や評価を表すために使用する語である。ここ では,「日本語の語彙特性」[13] に揭載された全21,690語 のうち, 印象語に用いられ得ると第一著者が判断した語を 50 語抜粋した。選出した語は, 文体に関する語と文章内容に 関する語に大別できる. 精選した印象語の一覧を表1に示す.

\section{表1 選定した印象語}

\begin{tabular}{|c|c|c|c|}
\hline \multicolumn{2}{|c|}{ 文章表現に関する印象語(22語) } & \multicolumn{2}{|c|}{ 文章内容に関する印象語(28語) } \\
\hline $\begin{array}{l}\text { 易しい } \\
\text { 巧みな } \\
\text { 丁寧な } \\
\text { 美しい } \\
\text { 清々しい } \\
\text { 流暢な } \\
\text { 特殊な } \\
\text { 説得力がある } \\
\text { 明瞭な } \\
\text { 曖昧な } \\
\text { 難しい }\end{array}$ & $\begin{array}{c}\text { しこし } \\
\text { たどたどしい } \\
\text { 味気ない } \\
\text { 不充分な } \\
\text { 大袈裟な } \\
\text { 細い } \\
\text { 単純な } \\
\text { 堅い } \\
\text { 長い } \\
\text { 複雑な } \\
\text { 斬新な }\end{array}$ & $\begin{array}{c}\text { 涙ぐましい } \\
\text { 素晴らしい } \\
\text { 好ましい } \\
\text { 感動的な } \\
\text { 的確な } \\
\text { 妥当な } \\
\text { 重要な } \\
\text { 心温まる } \\
\text { 独創的な } \\
\text { 充実した } \\
\text { 楽しい } \\
\text { 不快な } \\
\text { 怪しい } \\
\text { 辛辣な }\end{array}$ & $\begin{array}{c}\text { 憤慨した } \\
\text { 幻滅な } \\
\text { 怖し } \\
\text { 残念な } \\
\text { 不当な } \\
\text { 非常識な } \\
\text { 呆れる } \\
\text { 真実味 } \\
\text { 仕方が無い } \\
\text { 熱い } \\
\text { 強い } \\
\text { 予想外な } \\
\text { 不思議な } \\
\text { 懐かしい }\end{array}$ \\
\hline
\end{tabular}

なお，文章を選抜した基準は次の通りである。

・バイアスが強すぎる文章は除外

・公序良俗に反した内容を含む文章は除外

・他のHPのURLを参照する必要のある質問は除外

・短い文章と長い文章を織り交ぜることで, 文字の分量を バランス良く選抜

·内容, 論旨の類似した文章を重複しないよう選抜 ・各ジャンルから均等に選抜

12 組の質問回答文について, 全て異なるジャンルを均等 に織り交ぜるように，各組に対する回答記入用紙を回答記入 冊子 $\mathrm{A}, \mathrm{B}, \mathrm{C}$ に振り分けた。そして, 冊子単位では 冊子 $\mathrm{A} \rightarrow$ 冊子 $\mathrm{B} \rightarrow$ 冊子 $\mathrm{C}$ の順で回答を行ってもらい, 各冊子 においては以下の手順で回答を行ってもらう.

I. 冊子 $\mathrm{A}: \S 1$ 【Q1 $\rightarrow \mathrm{A} 1-1 \rightarrow \mathrm{A} 1-2 \rightarrow \mathrm{A} 1-3 \rightarrow \mathrm{A} 1-4 】$

$\Rightarrow \S 4$ IQ4 $\rightarrow$ A4-1 $\rightarrow$ A4-2 $\rightarrow$ A4-3 $\rightarrow$ A4-4】

$\Rightarrow \S 7$ 【Q7 $\rightarrow \mathrm{A} 7-1 \rightarrow \mathrm{A} 7-2 \rightarrow \mathrm{A} 7-3 \rightarrow \mathrm{A} 7-4 】$

$\Rightarrow \S 10 【 \mathrm{Q} 10 \rightarrow \mathrm{A} 10-1 \rightarrow \mathrm{A} 10-2 \rightarrow \mathrm{A} 10-3 \rightarrow \mathrm{A} 10-4 】$

II. 冊子 B : $\S 2$ IQ2 $\rightarrow \mathrm{A} 2-1 \rightarrow \mathrm{A} 2-2 \rightarrow \mathrm{A} 2-3 \rightarrow \mathrm{A} 2-4 】$

$\Rightarrow \S 5$ 【Q5 $\rightarrow \mathrm{A} 5-1 \rightarrow \mathrm{A} 5-2 \rightarrow \mathrm{A} 5-3 \rightarrow \mathrm{A} 5-4 】$

$\Rightarrow \S 8 【 \mathrm{Q} 8 \rightarrow \mathrm{A} 8-1 \rightarrow \mathrm{A} 8-2 \rightarrow \mathrm{A} 8-3 \rightarrow \mathrm{A} 8-4 】$

$\Rightarrow \S 11 【 \mathrm{Q} 11 \rightarrow \mathrm{A} 11-1 \rightarrow \mathrm{A} 11-2 \rightarrow \mathrm{A} 11-3 \rightarrow \mathrm{A} 11-4 】$

III. 冊子 C : § 3 【Q3 $\rightarrow$ A3-1 $\rightarrow$ A3-2 $\rightarrow$ A3-3 $\rightarrow$ A3-4】

$\Rightarrow \S 6$ IQ6 $\rightarrow$ A6-1 $\rightarrow$ A6-2 $\rightarrow$ A6-3 $\rightarrow$ A6-4】

$\Rightarrow \S 9$ 【Q9 $\rightarrow \mathrm{A} 9-1 \rightarrow \mathrm{A} 9-2 \rightarrow \mathrm{A} 9-3 \rightarrow \mathrm{A} 9-4 】$

$\Rightarrow \S 12 【 \mathrm{Q} 12 \rightarrow \mathrm{A} 12-1 \rightarrow \mathrm{A} 12-2 \rightarrow \mathrm{A} 12-3 \rightarrow \mathrm{A} 12-4 】$

ここで, §1〜§3はYahoo! オークションに関する質問,

$\S 4 〜 \S 6$ はパソコン・周辺機器に関する質問, $§ 7 〜 \S 9$ は恋愛相談・人間関係に関する質問， § $10 \sim \S 12$ は政治· 社会問題に関する質問を，それぞれ掲載している，また，Q はそのセクションで取り扱っている質問文，Aはその質問文 に対する回答文である。例えば, Q1 ならば 1 の質問文で あり、A1-1，A1-2，A1-3，A1-4はQ1に対する回答文であ る.ここで，質問文の後に回答文を読んでもらうのは，回答 文によっては質問文を読まないと何に対する回答かがわから ない文章があるからである。なお，各回答文のうち， A1-1，A2-1，、, A12-1 は実際にYahoo! 知恵袋で「べスト アンサー」に選出されたものである。ただし，利用者にはこ のことは伝えない. 


\section{2 印象評価のための利用者実験}

実験の結果，各印象語に対して 2,460 件（60個の文章 $\times$ 41 人：男性 33 名, 女性 8 名）の印象評価データが得られた. ここで，検定を行い，男女間に有意差があったため，男性の 回答結果のみを使用することとした。また，冊子間における 有意差を評価した結果，疲労による影響は無いと判断できた ので，全ての冊子の印象評価デー夕を使用することにした。

印象評価デー夕に対して，因子分析を実施し，解釈をより 容易にするために,バリマックス回転を施した [14]。ここで, 選択因子数を打ち切る基準として「固有值が 1.0 以上」 [15] を採用して，因子数を9個とした。そして，得られた9個の 因子を, 的確性, 不快性, 独創性, 容易性, 執拗性, 曖昧性, 感動性，努力性，熱烈性と呼ぶことにした，9つの因子とそ れぞれに対応する印象語を表 2 に示す。文献 [2] は，表2 で得られた因子と対応する印象語を用いて, 質問者が選択す る『ベストアンサー』の推定を試みている，本論文では，次 章に示す新たな特徵量を追加することによる推定の精度向上 と，その妥当性について議論する。

\section{4. 因子得点の推定}

\section{1 文章の特徵量}

\subsection{1 文章の構文情報}

文の長さや数, 品詞の数を求めるために, Text Seer [16] を用いて形態素解析を行った。ここでは，表3に示す 64 個 の特徵量を抽出している $[3]$.

文章中で, 複数回出現する単語が存在する可能性が高いこ とを考慮して, 語彙数と語数とは独立した特徵量として抽出 する。ここで, 語彙数とは, 文章中に同じ単語が複数回出現 した場合でも 1 個と数えることを表し, 語数とは, 単純に単 語の出現回数を表す。例えば，「私は私の夢を叶える」とい う文章を例にすると，「私」という単語が2回出現しているの で,「私」という1つの語彙に対して,「私」の語数は 2 である.

また, ひらがな, 漢字, カタカナ, 記号, 英数字に関して は, 出現の割合によって印象が変わると考えられる。 そこで,

表2 9つの因子と対応する印象語

\begin{tabular}{|c|c|c|c|}
\hline 因子 & \multicolumn{3}{|c|}{ 印象語 } \\
\hline 第1因子(的確性) & $\begin{array}{c}\text { 説得力がある } \\
\text { 素晴らしい } \\
\text { 真実味がある } \\
\text { 充実した } \\
\text { 丁寧な }\end{array}$ & $\begin{array}{c}\text { 流暢な } \\
\text { 好ましい } \\
\text { 清々しい } \\
\text { 美しい }\end{array}$ & $\begin{array}{l}\text { 重要な } \\
\text { 巧みな } \\
\text { 妥当な } \\
\text { 的確な }\end{array}$ \\
\hline 第2因子(不快性) & $\begin{array}{l}\text { 不快な } \\
\text { 残念な } \\
\text { 幻滅した }\end{array}$ & $\begin{array}{c}\text { 憤慨した } \\
\text { 不当な } \\
\text { 怖し) }\end{array}$ & $\begin{array}{c}\text { 非常識な } \\
\text { 呆れる }\end{array}$ \\
\hline 第3因子(独創性) & $\begin{array}{c}\text { 独創的な } \\
\text { 斬新な }\end{array}$ & $\begin{array}{l}\text { 予想外な } \\
\text { 不思議な }\end{array}$ & 特殊な \\
\hline 第4因子(容易性) & 易しい & 明瞭な & 難しい) \\
\hline 第5因子(執拗性) & 細かい & しつこい & 長し \\
\hline 第6因子(曖昧性) & 曖昧な & 不充分な & \\
\hline 第7因子 (感動性) & 心温まる & 感動的な & \\
\hline 第8因子(努力性) & 涙ぐましい & & \\
\hline 第9因子(熱烈性) & 熱い) & 力強い & \\
\hline
\end{tabular}

表3 文章の文体・内容に関する特徵量

\begin{tabular}{|c|c|c|c|}
\hline$f$ & 特徵量 & $f$ & 特徵量 \\
\hline$f 1$ & 文字数 & f33 & 感動詞 (語数) \\
\hline f2 & 名詞 (語彙数) & f34 & 助動詞 (語数) \\
\hline f3 & 動詞 (語彙数) & f35 & 助詞 (語数) \\
\hline $\mathrm{f} 4$ & 形容詞 (語彙数) & f36 & ひらがな(\%) \\
\hline f5 & 副詞 (語彙数) & f37 & 漢字(\%) \\
\hline f6 & 連体詞 (語彙数) & f38 & カタカナ (\%) \\
\hline f7 & 接続詞(語彙数) & f39 & 記号(\%) ）－１－ \\
\hline f8 & 感動詞 (語彙数) & $\mathrm{f} 40$ & TTR \\
\hline f9 & 助動詞 (語彙数) & $\mathrm{f} 41$ & 全角記号（％) \\
\hline$f 10$ & 助詞 (語彙数) & $\mathrm{f} 42$ & 英数字 (\%) \\
\hline$f 11$ & 接頭詞 & $\mathrm{f} 43$ & 全角英数字 (\%) \\
\hline$f 12$ & 記号(語彙数) & $\mathrm{f} 44$ & 半角英数字 (\%) \\
\hline$f 13$ & 文数 & $\mathrm{f} 45$ & 名詞 (\%) \\
\hline f14 & 文の長さ平均(語数) & $\mathrm{f} 46$ & 動詞 (\%) \\
\hline f15 & 文の長さ平均(字数） & f47 & 形容詞(\%) \\
\hline f16 & ひらがな(語数) & $\mathrm{f} 48$ & 副詞(\%) \\
\hline f17 & 漢字(語数) & f49 & 連体詞 (\%) \\
\hline f18 & カタカナ(語数) & $f 50$ & 接続詞(\%) \\
\hline f19 & 記号(語数) & f51 & 感動詞 (\%) \\
\hline$f 20$ & 全角記号 (語数) & f52 & 助動詞 (\%) \\
\hline$f 21$ & 英数字 (語数) & f53 & 助詞 (\%) \\
\hline$f 22$ & 全角英数字 (語数) & f54 & $\lceil! 」$ の数 \\
\hline$f 23$ & 半角英数字 (語数) & f55 & 「?」の数 \\
\hline$f 24$ & 語数 & f56 & 句点の数 \\
\hline$f 25$ & 語彙数 & f57 & 読点の数 \\
\hline f26 & 未知語 & f58 & 中点の数 \\
\hline f27 & 名詞 (語数) & f59 & 3点リーダの数 \\
\hline$f 28$ & 動詞 (語数) & $\mathrm{f} 60$ & 鍵括弧の数 \\
\hline$f 29$ & 形容詞 (語数) & f61 & 鍵括弧閉の数 \\
\hline$f 30$ & 副詞 (語数) & f62 & 括弧の数 \\
\hline f31 & 連体詞 (語数) & f63 & 括弧閉の数 \\
\hline f32 & 接続詞(語数) & f64 & $\lceil/ 」 の$ 数 \\
\hline
\end{tabular}

それぞれの出現回数だけではなく，それらを含む文章そのも のの長さ及び文章内に抒ける含有率（全文字数に対する当該 字種の文字数の比率）も考慮する必要があると考え，ひらが な，漢字，カタカナなどの文章における含有率も特徵量とし た。例えば，表3のf16の「ひらがな（語数）」は，文章内の ひらがなの単語数を表し，f36の「ひらがな（\%)」は文章に おけるひらがなの含有率を表している。

f26の「未知語」とは, Text Seerをデフォルトの状態で 使用し,「未知語」と判定された語数を表している。なお, 未知語と判定された語は, 名詞または記号として辞書に登録 した上で, 改めて形態素解析を行った. f40のTTR（Type Token Ratio）は, 語数に対する語彙数の比率を表している.

重回帰分析を実施する際，複数の説明変数同士は無相関で あるという前提が必要であり, 説明変数は以下の条件を考慮 して選択しなければならない [17].

a) 目的変数との相関係数が高い説明変数の選択

b）高い相関を示す説明変数の組の一方を説明変数から除外 ここで，b）の事項に反した場合，偏回帰係数が正しく求 まらないことがあり，この状態を多重共線性という［17．

多重共線性を回避するために，表3に示す説明変数に関 して, 説明変数同士の相関係数の值を調べ，0.7 以上である 組に関しては，一方を説明変数から除外した，その結果， 説明変数は39個となった。これらを表 3 に網掛けを施して 示す. 


\subsection{2 単語心像性}

NTTデータベースシリーズ [13]には，人が主観的に評定を 行ったデータと，14年間にわたる新聞に単語や文字が出現し た回数を数えた客観的データが収録されている.これらのデー 夕は，人間の言語処理過程に大きな影響を及ぼすものとして 広く知られており，収録されている各特性值や特性值間の関 係は，日本語自体の特性を示しているといえる [18]，これら のデー夕も文章の特徵量として有用であると考えられる.

これらのデータの中でも, 単語心像性を文章の特徽量に追 加する。単語心像性とは, 単語から喚起される様々なイメー ジが, どの程度思い浮かべやすいかを示す主観的特性である。 例えば,「りんご」という言葉を聞くと, 赤・黄・緑の丸い 形の果物, 甘くみずみずしい味・匂い, サクッとした音や歯 ざわり，持った時の感触を思い浮かべることができる，

ここで, 単語心像性の特性值は, 「単語の非言語的感覚イ メージの喚起力」に関して,「1：イメージを非常に思い浮 かべにくい（または思い浮かばない）～7：イメージを非常 に思い浮かべやすい」の7段階尺度で評定させた值である. 新聞記事を対象としたデー夕 [13] と, 質問回答文の文章を 形態素解析したデー夕に共通の単語が存在するならば，その 単語の単語心像性の值を特性值として使用する。なお，形態 素解析した単語が [13] のデー夕に含まれていない場合, そ の単語の単語心像性の值は考慮しないものとして処理する。

また，同じ単語の表記でも，意味または読みが異なる場 合がある，例えば，意味が異なる例としては，「アース」と いう単語は,「電気を逃がすために接地すること」,「地球」, 「殺虫剤（メーカー）」の意味がある。読みが異なる例とし ては,「間」という言葉は,「あいだ」「「ま」の読みがある。 このような単語が形態素解析したデータに存在する場合は, 文脈から判断しながら手動で意味または読みを決定する.

このようにして, 単語心像性の特徴量を抽出した。 これを 表4に示す，特徴量としては，単語心像性に該当した単語の 数や該当した単語の割合や，単語心像性の值が 1 点台 $(1.0$

\section{表4 単語心像性の特徵量}

\begin{tabular}{|c|c|c|c|}
\hline 1 & 語彙数(当該単語) & 22 & 語数(1.0～2.0未満) \\
\hline 2 & 語数(当該単語) & 23 & 語数(1.0～1.5未満) \\
\hline 3 & 当該単語率 & 24 & 語数(1.5～2.0未満) \\
\hline 4 & 語彙数(1.0～2.0未満) & 25 & 語数(2.0～3.0未満) \\
\hline 5 & 語彙数(1.0～1.5未満) & 26 & 語数(2.0～2.5未満) \\
\hline 6 & 語彙数(1.5～2.0未満) & 27 & 語数(2.5～3.0未満) \\
\hline 7 & 語彙数(2.0～3.0未満) & 28 & 語数(3.0～4.0未満) \\
\hline 8 & 語彙数(2.0～2.5未満) & 29 & 語数(3.0～3.5未満) \\
\hline 9 & 語彙数(2.5～3.0未満) & 30 & 語数(3.5～4.0未満) \\
\hline 10 & 語彙数(3.0～4.0未満) & 31 & 語数(4.0～5.0末満) \\
\hline 11 & 語彙数(3.0～3.5未満) & 32 & 語数(4.0～4.5未満) \\
\hline 12 & 語彙数(3.5～4.0未満) & 33 & 語数(4.5～5.0末満) \\
\hline 13 & 語彙数(4.0～5.0未満) & 34 & 語数 (5.0～6.0未満) \\
\hline 14 & 語彙数(4.0～4.5未満) & 35 & 語数（5.0～5.5未満) \\
\hline 15 & 語彙数(4.5～5.0末満) & 36 & 語数 (5.5～6.0未満) \\
\hline 16 & 語彙数(5.0～6.0未満) & 37 & 語数(6.0～7.0未満) \\
\hline 17 & 語彙数(5.0～5.5未満) & 38 & 語数 (6.0～6.5未満) \\
\hline 18 & 語彙数(5.5～6.0未満) & 39 & 語数(6.5～7.0末満) \\
\hline 19 & 語彙数(6.0～7.0未満) & & \\
\hline 20 & 語彙数(6.0～6.5未満) & & \\
\hline 21 & 語彙数(6.5～7.0未満) & & \\
\hline
\end{tabular}

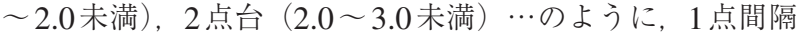
で特徵量をとったものや, 1.0 以上 1.5 未満, 1.5 以上 2.0 未満, ․のように, 0.5 点間隔で特徵量をとったものを抽出した $[3]$.

ここでも, 多重共線性を回避するために, 表 4 に示す特徴 量間同士に関して, それぞれの相関係数を調べた. その結果, 特徵量間同士の相関係数のほとんどが 0.7 以上となり, 各特 徵量の間に強い相関が見られることがわかった。このうち, 相関係数が 0.7 未満の組である「語数 $(4.0 \sim 5.0$ 未満 $) 」$,

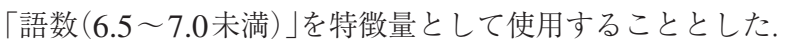
ここでは，それぞれをf65, f66とする。

さらに, 表3 と表4で網掛けを施した計 39 個の特徵量に関 して, 多重共線性を考慮した結果, f1の「文字数」を特徴量 から外すこととし, 残り 38 個の特徵量を説明変数として使 用することとする。

\subsection{3 文末表現}

ここでは，西原らが使用している文末表現 [4]を特徴量 に採用した。西原らは，文末表現のパターンを「質問とべス トアンサーにのみ含まれる文末表現」と定義している [4]. これに対し，当研究では「全ての質問文と回答文に含まれる 文末表現」と定義する。文末表現を表 5 に示す。ここで，例 えば,「ぞ」を例にすると,「ぞ(語数)」は文中に出現する「ぞ」 の数であり，「ぞ (文末語数)」は文末に出現する「ぞ」の数

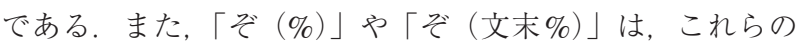
含有率である。ここでも, 多重共線性を考慮して, 表5で網 掛けを施した64個の特徵量を採用する.

以上のことから, 表3, 表 4 , 表 5 で網掛けを施した特徴量の 中で, 相関が強いために除外したのは前述のf1のみであった。 残りの64個の特徵量をまとめて表6に示す，以降では，これ らを $\mathrm{g} 1, \mathrm{~g} 2, \cdots と$ 表記することにし, これらを推定に使用する。

\section{表 5 文末表現の特徵量}

\begin{tabular}{c|c}
\hline$f$ & 特徵量 \\
\hline$f 67$ & ぞ(語数) \\
$f 68$ & だ(語数) \\
$f 69$ & よ(語数) \\
$f 70$ & ね(語数) \\
$f 71$ & か(語数) \\
$f 72$ & な(語数) \\
$f 73$ & し(語数) \\
$f 74$ & です(語数) \\
$f 75$ & ます(語数) \\
$f 76$ & たし(語数) \\
$f 77$ & ない(語数) \\
$f 78$ & ぞ(文末語数) \\
$f 79$ & だ(文末語数) \\
$f 80$ & よ(文末語数) \\
$f 81$ & ね(文末語数) \\
$f 82$ & か(文末語数) \\
$f 83$ & な(文末語数) \\
$f 84$ & し(文末語数) \\
$f 85$ & です(文末語数) \\
$f 86$ & ます(文末語数) \\
$f 87$ & たし(文末語数) \\
$f 88$ & ない(文末語数) \\
$f 89$ & ぞ(\%) \\
$f 90$ & だ(\%) \\
\hline
\end{tabular}

\begin{tabular}{|c|c|}
\hline$f$ & 特徵量 \\
\hline f91 & L(\%) \\
\hline f92 & ね(\%) \\
\hline f93 & か(\%) \\
\hline f94 & な(\%) \\
\hline f95 & $し(\%)$ \\
\hline f96 & です(\%) \\
\hline f97 & ます (\%) \\
\hline f98 & たい(\%) \\
\hline f99 & なし)(\%) \\
\hline$f 100$ & ぞ(文末\%) \\
\hline f101 & だ(文末\%) \\
\hline f102 & よ(文末\%) \\
\hline f103 & ね(文末\%) \\
\hline f104 & か(文末\%) \\
\hline f105 & な(文末\%) \\
\hline f106 & し(文末\%) \\
\hline f107 & です (文末\%) \\
\hline f108 & ます(文末％) \\
\hline f109 & たい(文末％) \\
\hline f110 & ない(文末\%) \\
\hline$f 111$ & ですか(語数) \\
\hline f112 & なしです (語数) \\
\hline f113 & ますか(語数) \\
\hline f114 & ました(語数) \\
\hline
\end{tabular}




\section{2 推 定 結 果}

\subsection{1 単項のみを考慮した重回帰分析}

3. で使用した 60 個の質問回答文に対し, 表 6 に示す 64 個 の特徴量を説明変数とし，9因子の因子得点を目的変数とし て,ステップワイズ選択法による重回帰分析 [19]を行った 結果，重回帰式 (1) が得られた。

$$
\begin{aligned}
y_{1} & =0.00295 g_{37}+0.150 g_{12}+0.0609 g_{59}+0.0533 g_{21}+0.0105 g_{7} \\
& -0.113 g_{29}+0.0896 g_{9}+0.0151 g_{19}-0.750 \\
y_{2} & =1.73 g_{44}+1.79 g_{50}-0.115 g_{1}+0.110 g_{43}+0.0341 g_{8}-0.172 g_{12} \\
& +0.261 \\
y_{3} & =0.183 g_{52}+0.0585 g_{8}-0.104 g_{43}+0.776 g_{50}+0.0829 g_{60} \\
& -0.0808 \\
y_{4} & =-0.0468 g_{37}-0.0842 g_{52}+0.0915 g_{9}-0.178 g_{45}+0.305 \\
y_{5} & =0.0794 g_{1}+0.0152 g_{6}+0.107 g_{29}+0.0132 g_{15}+0.00310 g_{5} \\
& +0.0302 g_{4}+0.415 g_{49}+0.563 g_{50}-1.14 \\
y_{6} & =-0.0759 g_{31}-0.11163 g_{43}-0.0618 g_{56}-0.0342 g_{8}-0.126 g_{55} \\
& -0.772 g_{44}-0.691 g_{50}-0.125 g_{25}+0.698 \\
y_{7} & =0.391 g_{13}+0.0747 g_{10}-0.920 g_{62}+0.106 g_{23}-0.265 \\
y_{8} & =0.0871 g_{1}+0.0788 g_{60}+0.104 g_{23}-0.00560 g_{20}-0.00905 g_{8} \\
& -0.388 \\
y_{9} & =0.207 g_{52}-0.0169 g_{16}+0.864 g_{50}+0.373 g_{51}+0.802 g_{44} \\
& +0.0406
\end{aligned}
$$

\begin{tabular}{|c|c|}
\hline g & 特徵量 \\
\hline g1 & 助動詞 (語彙数) \\
\hline g2 & 接頭詞 \\
\hline g3 & 記号(語彙数) \\
\hline g4 & 文数 \\
\hline g5 & 文の長さ平均(字数) \\
\hline g6 & カタカナ (語数) \\
\hline g7 & 全角記号 (語数) \\
\hline g8 & 全角英数字 (語数) \\
\hline g9 & 形容詞 (語数) \\
\hline g10 & 副詞 (語数) \\
\hline g11 & 連体詞 (語数) \\
\hline g12 & 接続詞(語数) \\
\hline g13 & 感動詞 (語数) \\
\hline g14 & ひらがな(\%) \\
\hline g15 & 漢字(\%) \\
\hline g16 & カタカナ (\%) \\
\hline g17 & 記号 (\%) \\
\hline g18 & TTR \\
\hline g19 & 全角記号(\%) \\
\hline g20 & 英数字(\%) \\
\hline g21 & 全角英数字(\%) \\
\hline g22 & 名詞(\%) \\
\hline g23 & 形容詞(\%) \\
\hline g24 & 副詞(\%) \\
\hline g25 & 連体詞(\%) \\
\hline g26 & 接続詞(\%) \\
\hline g27 & 感動詞(\%) \\
\hline g28 & $\lceil! 」 の$ 数 \\
\hline g29 & 「?」の数 \\
\hline g30 & 句点の数 \\
\hline g31 & 読点の数 \\
\hline g32 & 中点の数 \\
\hline
\end{tabular}

表6 多重共線性を考慮して採用した説明変数
この時の重相関係数を表7の「単項のみ」の列に示す。 第 1 から第 6 までの 6 因子は推定精度がやや良好であり， 残りの第7から第 9 までの3因子は推定精度が不良であると いう結果が得られた。

\subsection{2 二次の項を考慮した重回帰分析}

次に，単項のみの分析で使用した64個の説明変数に関し て，二次の項を考慮する。二次の項とは，説明変数同士の 積を意味する。二次の項同士の多重共線性を考慮した結果, 説明変数の数は 218 個となった。単項の場合と同様に，3.の 印象評価実験で使用した60個の質問回答文に対し，218個 の特徵量を説明変数とし, 因子得点を目的変数として, ステッ プワイズ選択法による重回帰分析 [19]を行った。この結果， 重回帰式 (2) が得られた。

この時の重相関係数を表 7 の二次項も考慮」の列に示す. 第 3 因子（独創性）と第 6 因子（曖昧性）以外の 7 因子に関 しては，全ての值が 0.9 以上をとっているので，推定精度が 良好であるといえる．第 3 因子と第 6 因子は值が 0.9 に及ば なかったが，それでも推定精度がやや良好であるといえる。

\section{5. 評 価}

\section{1 推定の良好性}

推定の良好性を，推定誤差により評価する。実験の因子 得点とその推定值の平均誤差の絶対值を求め, 表 8 に示す. 全体の誤差平均は非常に小さく，どの因子も因子得点に近い 推定值が求まっていると考えられる。その中でも，第 1 因子 (的確性)，第 5 因子（執拗性），第 7 因子（感動性），第9因 子 (熱烈性) は, 残差平均の絶対值が特に小さくなっており, 観測值に特に近い予測結果が出ていると思われる.

表7 重相関係数

\begin{tabular}{c|c|c}
\hline \multirow{2}{*}{ 因子 } & \multicolumn{2}{|c}{ 重相関係数 } \\
\cline { 2 - 3 } & 単項のみ & 二次項も考慮 \\
\hline 第1因子(的確性) & 0.832 & 1.000 \\
第2因子(不快性) & 0.774 & 0.947 \\
第3因子(独創性) & 0.744 & 0.877 \\
第4因子(容易性) & 0.728 & 0.908 \\
第5因子(執拗性) & 0.893 & 0.966 \\
第6因子(曖昧性) & 0.872 & 0.899 \\
第7因子(感動性) & 0.581 & 0.997 \\
第8因子(努力性) & 0.650 & 0.904 \\
第9因子(熱烈性) & 0.683 & 0.954 \\
\hline
\end{tabular}

\section{表 8 各因子の残差の絶対値}

\begin{tabular}{c|c}
\hline 因子 & 残差の絶対值 \\
\hline 第1因子(的確性) & 0.0000420 \\
第2因子(不快性) & 0.114 \\
第3因子(独創性) & 0.164 \\
第4因子(容易性) & 0.124 \\
第5因子(執拗性) & 0.0874 \\
第6因子(曖昧性) & 0.147 \\
第7因子(感動性) & 0.0202 \\
第8因子(努力性) & 0.112 \\
第9因子(熱烈性) & 0.0858 \\
\hline 残差平均 & 0.0949 \\
\hline
\end{tabular}




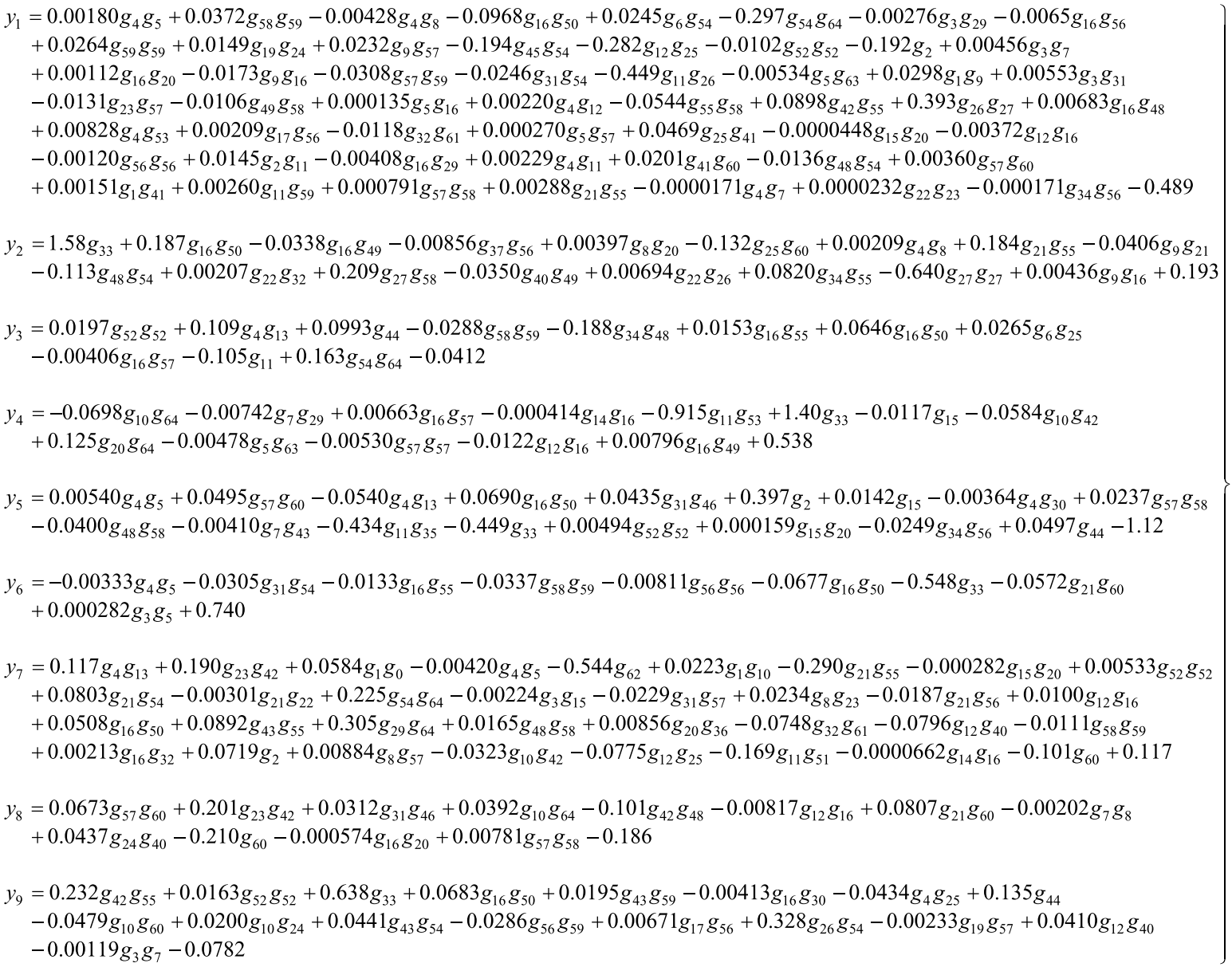

\section{2 文末表現の効果}

推定における文末表現の効果を調べるために，文末表現の 特徵量 $(\mathrm{g} 39 \sim \mathrm{g} 64)$ のみを説明変数とし, 9因子の因子得点を 目的变数として, 重回帰分析を行った。この時の重相関係数 を, 構文情報と単語心像性のみを用いた推定結果 $(\mathrm{g} 1 \sim \mathrm{g} 38)$ と, 構文情報, 単語心像性と文末表現の全てを用いた推定結 果（g1〜 g64）をあわせて表9に示す. ここでは, 二次の項を 考慮した場合のみを示している.

ここで, $\mathrm{g} 1 \sim \mathrm{g} 38$ と39〜 g64 とを, 重相関係数の点で比 較する. $\mathrm{g} 1 \sim \mathrm{g} 38$ は, 第 1 因子 (的確性), 第3 因子 (独創性), 第 4 因子（容易性）, 第 5 因子（執拗性）の因子得点の推定 精度が, g39〜g64を上回っている. 一方, g39〜 g64は, 第2 因子 (不快性), 第6因子 (曖昧性), 第7 因子 (感動性),

\section{表9 分析結果の重相関係数}

\begin{tabular}{c|c|c||c}
\hline 因子 & $\begin{array}{c}\text { 構文情報亡単語心像性 } \\
(g 1 \sim g 38)\end{array}$ & $\begin{array}{c}\text { 文末表現 } \\
(\text { g39 g64) }\end{array}$ & $\begin{array}{c}\text { 全特徵量 } \\
(\mathrm{g} 1 \sim \mathrm{g} 4)\end{array}$ \\
\hline 第1因子(的確性) & 0.972 & 0.795 & 1.000 \\
第2因子(不快性) & 0.703 & 0.834 & 0.947 \\
第3因子(独創性) & 0.697 & 0.637 & 0.877 \\
第4因子(容易性) & 0.862 & 0.797 & 0.908 \\
第5因子(執拗性) & 0.864 & 0.705 & 0.966 \\
第6因子(曖昧性) & 0.690 & 0.780 & 0.899 \\
第7因子(感動性) & 0.678 & 0.895 & 0.997 \\
第8因子(努力性) & 0.614 & 0.695 & 0.904 \\
第9因子(熱烈性) & ------ & 0.859 & 0.954 \\
\hline
\end{tabular}

第 8 因子（努力性）, 第9因子（熱烈性）の因子得点の推定 精度が, $\mathrm{g} 1 \sim \mathrm{g} 38$ を上回っている. 従って, 文末表現に特 化した特徵量（g39～g64）と, 構文情報と単語心像性に着 目した特徴量（g1〜 g38）とでは, それぞれ長けている点と 不足している点とがあることが分かる.

一方，これら両方を特徵量として考慮すると，推定精度 が非常に良くなる。これは，互いの不足している点を補い 合うことにより，推定精度が非常に良くなるものではない かと考えられる。従って, 文末表現にも, 文章の因子得点 の推定精度に一定の効果があるが, それだけでなく, 文章 の文の数や品詞の数など, 文章全体の文体や内容にも着目 することにより，文章の因子得点の推定精度が向上するも のと考えられる.

\section{6. 推定の妥当性について}

ここでは, 各因子の因子得点の推定の妥当性についての確 認を試みる。まず，得られた重回帰式（2）に含まれる変数 に関して, 変数の值に偏回帰係数を乗じた值の和と, 目的変 数との相関係数が 0.6 以上になるように選択し, 因子得点推 定において重要な特徵量（代表特徵量と呼ぶ）を求める。そ して, 因子得点が高い文章において代表特徴量が確かに使用 されているかを確認する。また，因子得点が低い文章におい て代表特徴量が使用されていないかを確認する. 因子得点が 
高い文章を表 10 に示し, 因子得点が低い文章を, 因子得点 の実值・推定值と併せて表 11 に示す。以下，それぞれの因 子に対する確認結果を示す

- 第1因子（的確性）

g4_g5 (文数*文の長さ平均 (字数) ), g58_g59（「ます」(\%) *「ない」(\%)，g4_g12（文数*接続詞（語数)）を選択する と, 目的変数との相関係数が 0.730 となった. 3 変数とも符 号は正である. 従って, 文数, 文の長さ平均 (字数), 接続詞 が多い場合や，「ます」，「ない」の割合が高い場合は，的確 性の因子得点が高くなると考えられる。

\section{表10 因子得点が高い文章の例}

\begin{tabular}{|c|c|c|}
\hline \multirow[t]{2}{*}{ 因子 } & 文番号 & 投稿内容 \\
\hline & [実值/推定值］ & \\
\hline 第1因子 & $\overline{\mathrm{A} 4-1}$ & Microsoft Officeをお持ちなら、Microsoft Photo Editorというソフトが付いています。 \\
\hline \multirow[t]{3}{*}{ (的確性) } & {$[1.12 / 1.12]$} & $\begin{array}{l}\text { スタート } \rightarrow \text { ず゙てのプログラム } \rightarrow \text { Microsoft Officeツールというフォルダにたいていあります。インストールされ } \\
\text { ていない場合もありますから、その場合はOffice CDより追加でインストールしてください。 }\end{array}$ \\
\hline & & このソフトで修正したい画像を読み込み、イメージー自動調整を実行すると、かなりきれいになります。 \\
\hline & & また、手動でも各種の調整が可能です。 \\
\hline 第2因子 & A5-4 & 何を偉そうに、たかがパソコン講師の分際で威張ってるんだよ。 \\
\hline \multirow[t]{8}{*}{ （不快性） } & {$[1.60 / 1.60]$} & \\
\hline & & $\begin{array}{l}\text { 此処で質問してる人は偉そうに、専門用語を並び立てて回答してもその専門用語が判らんのだよ。だから質問し } \\
\text { てるんだ。 }\end{array}$ \\
\hline & & 蛸の臯の様に頭に上ってる様なやつに、BA何か付けるもんか。もう此処に来るな。 \\
\hline & & パソコン講師。 \\
\hline & Q5 & 私の回答はプロフェッショナルなものであり「授業」であります。指導的立場からの投稿であるので、必ずBAに \\
\hline & {$[1.47 / 1.47]$} & 選ばれるべき回答を書いております。しかるに、BAをつけない不届きものは何を考えているのか。教えていただ \\
\hline & & きたい。 \\
\hline & & パソコン講師 \\
\hline 第3因子 & $\overline{\mathrm{A} 10-1}$ & 天下乱れるとき、覇を征する時ぞ \\
\hline \multirow[t]{12}{*}{ (独創性) } & {$[1.60 / 1.60]$} & $\cdots \cdots \cdots \cdots \cdots$ \\
\hline & A2-1 & うん、お前だけ! \\
\hline & {$[1.56 / 1.49]$} & ……....................... ' \、 \\
\hline & & (................................. $\backslash$ \\
\hline & & 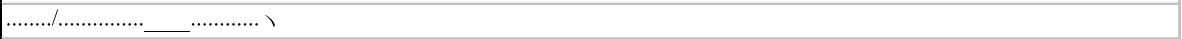 \\
\hline & & ...../.........../川 / ノ.......... \ \\
\hline & & $\ldots(\bullet \cdots(ミ / \frown 、 三) \ldots \bullet)$ \\
\hline & & 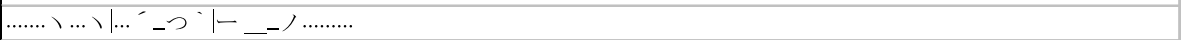 \\
\hline & & 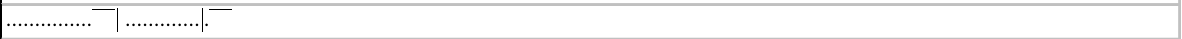 \\
\hline & & 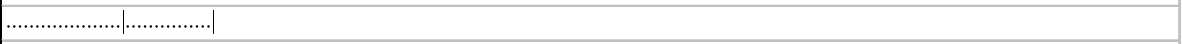 \\
\hline & & $\ldots \ldots \ldots \ldots \ldots \ldots \ldots \ldots \ldots \ldots \ldots \ldots$ \\
\hline & & <イオマエ茸 > \\
\hline 第4因子 & A1-4 & 自分に正直でとてもいい。初めは何事も思ったように好きにやりなさい。 \\
\hline （容易性） & {$[0.706 / 0.220]$} & \\
\hline 第5因子 & A9-1 & このトピックを見て俺とまったく同じようなので寄ってみました。俺も実際メールの回数とかこんなに彼女の事 \\
\hline （執拗性） & {$[1.37 / 1.38]$} & $\begin{array}{l}\text { 思ってるのになんでだろうとか考えてわざとそっけなくしたり仕返し的な事をして自分を表現してます。でも良 } \\
\text { く考えるとちっさい自分だなと反省するんただけど、また同じ事してるんです。相手を思う気持ちを抑える事が相 } \\
\text { 手に対する思いやりだと最近思うようになりました。自分は彼女の事を好きなら気持ちは抑えて他の事で彼女を } \\
\text { 思ったらどうかな?押し付け的に彼女を思うと相手は素直に受け入れてくれないと思うよ。女は受身だし気まま } \\
\text { なもんだと決め付けるのではなくてさりげなく相手を思い肝心なとき表現出来て長く気持ちを持たせる努力が自 } \\
\text { 分も成長出来るし相手を理解出来るんじゃないかな? }\end{array}$ \\
\hline 第6因子 & A4-2 & デジカメに付いていた編集ソフトを、インストールして明るさを変更する。 \\
\hline （曖昧性） & {$[1.23 / 0.646]$} & \\
\hline 第7因子 & A8-2 & 私もあなたと一緒で心配性でネガティブで性格も暗いほうですし・・・。普通にしやべっているつもりがなんか \\
\hline \multirow[t]{6}{*}{ （感動性） } & {$[0.957 / 0.957]$} & 私の声が小さいみたいで・・・ \\
\hline & & 彼からも「なんでそうマイナス思考になるんだ?」って言われるときあるし。 \\
\hline & & でも人それぞれ考え方、性格は違うし。 \\
\hline & & あなたは今こうやって質問してきていることが \\
\hline & & プラスになっているんではないかと思います。 \\
\hline & & お互い頑張りましょう！！ \\
\hline 第8因子 & A10-4 & 戦いますよ。守るものがあるからね。 \\
\hline \multirow[t]{5}{*}{ （努力性） } & {$[0.951 / 0.805]$} & 妻と子供は守りたいし、守るべきものがあるのに、行動を起こさない父親の姿を子供に見せたくない。 \\
\hline & & 戦わない人ってのは、守るべきものがまだ見つかってないんだと思う。 \\
\hline & Q7 & 僕は人の話の内容を聞き取る力が人1倍弱いと感じてます。そこで、ラジオを最近になってよく使い、聞く能力を \\
\hline & {$[0.730 / 0.307]$} & 高めているつもりで寸が、これって効果あるのでしょうか? \\
\hline & & カテがわからなかったので、ここで質問してすいません。 \\
\hline 第9因子 & A10-4 & 戦いますよ。守るものがあるからね。 \\
\hline \multirow[t]{4}{*}{ （熱烈性） } & {$[1.34 / 1.30]$} & 妻と子供は守りたいし、守るべきものがあるのに、行動を起こさない父親の姿を子供に見せたくない。 \\
\hline & & 戦わない人ってのは、守るべきものがまだ見つかってないんだと思う。 \\
\hline & $\mathrm{A} 10-1$ & 天下乱れるとき、覇を征する時ぞ \\
\hline & {$[1.05 / 0.960]$} & $\cdots \cdots \cdots \cdots \cdots \cdot \ldots$ \\
\hline
\end{tabular}


表11 因子得点が低い文章の例

\begin{tabular}{|c|c|c|}
\hline 因子 & 文番号 & 投稿内容 \\
\hline & [実值/推定值］ & \\
\hline 第1因子 & A10-1 & 天下乱れるとき、覇を征する時ぞ \\
\hline (的確性) & {$[-0.955 /-0.955]$} & $\cdots \cdots \cdots \cdots \cdots$ \\
\hline 第2因子 & Q7 & 僕は人の話の内容を聞き取る力が人1倍弱いと感じてます。そこで、ラジオを最近になってよく使い、聞く能力を \\
\hline \multirow[t]{7}{*}{ （不快性） } & {$[-0.620 /-0.470]$} & 高めているつもりですが、これって効果あるのでしょうか? \\
\hline & & カテがわからなかったので、ここで質問してすいません。 \\
\hline & A4-1 & Microsoft Officeをお持ちなら、Microsoft Photo Editorというソフトが付いています。 \\
\hline & {$[-0.546 /-0.585]$} & スタートーす心゙てのプログラム Microsoft Officeツールというフォルダにたいていあります。インストールさ \\
\hline & & れていない場合もありますから、その場合は0ffice CDより追加でインストールしてください。 \\
\hline & & このソフトで修正したい画像を読み込み、イメージー自動調整を実行すると、かなりきれいになります。 \\
\hline & & また、手動でも各種の調整が可能です。 \\
\hline 第3因子 & Q4 & パソコン初心者です。 \\
\hline (独創性) & {$[-0.599 /-0.569]$} & $\begin{array}{l}\text { デジカメで撮った画像をプリントアウトしたところ画像が暗いのですが、明るくする方法をご存知の方回答を掠 } \\
\text { 願いします。 }\end{array}$ \\
\hline 第4因子 & Q2 & ここでよく「○○に入札しても大丈夫?」っていう質問を目にするけど、そんな人に限って「ID非公開」。 \\
\hline \multirow[t]{3}{*}{ （容易性） } & {$[-0.936 /-0.974]$} & 検討しているオークションIDやURLを晒すということは、入札するのは別IDであっても、入札＝大公開することに \\
\hline & & なると思うんだけど、わかってんだろうが? ? \\
\hline & & ちょっと心配になるのは、俺だけだろうか。 \\
\hline 第5因子 & A4-2 & デジカメに付いていた編集ソフトを、インストールして明るさを変更する。 \\
\hline (執拗性) & {$[-0.864 /-0.687]$} & \\
\hline 第6因子 & A5-4 & 何を偉そうに、たかがパソコン講師の分際で威張ってるんだよ。 \\
\hline \multirow[t]{4}{*}{ （曖昧性） } & {$[-0.748 /-0.748]$} & 此処で質問してる人は偉そうに、専門用語を並び立てて回答してもその専門用語が判らんのだよ。だから質問し \\
\hline & & てるんだ。 \\
\hline & & 蛸の粪の様に頭に上ってる様なやつに、BA何か付けるもんか。 もう此処に来るな。 \\
\hline & & パソコン講師。 \\
\hline 第7因子 & Q1 & 初めて出品します。 \\
\hline \multirow[t]{3}{*}{ （感動性） } & {$[-0.636 /-0.628]$} & 「悪い評価のある方・神経質な方・子供や仕事を理由に入金が遅れる方・端数入札をされる方・評価をしない \\
\hline & & 方・あいさつのできない方」は、 \\
\hline & & 入札お断りにしようと思うのですが、感じ悪いですか? \\
\hline 第8因子 & A1-4 & 自分に正直でとてもいい。初めは何事も思ったように好きにやりなさい。 \\
\hline \multirow[t]{5}{*}{ (努力性) } & {$[-0.517 /-0.186]$} & \\
\hline & A4-4 & おすすめは「デジカメの達人」で補正する \\
\hline & {$[-0.466 /-0.360]$} & しかし、あれは有料ソフトなので、強要はしない \\
\hline & & デジカメで撮った写真は全部補正掛けてそれを印刷する。 \\
\hline & & ページに載せるときも補正した後カットしてリサイズしたものを載せる \\
\hline 第9因子 & Q4 & パソコン初心者です。 \\
\hline （熱烈性） & {$[-0.504 /-0.263]$} & $\begin{array}{l}\text { デジカメで撮った画像をプリントアウトしたところ画像が暗いのですが、明るくする方法をご存知の方回答をお } \\
\text { 願いします。 }\end{array}$ \\
\hline
\end{tabular}

表10の例でも，その傾向が見られる。また，表11の例は

1 文であり, 前述の特徴量は確かに使われていない

・第2因子（不快性）

g16_g49 (カタカナ (\%) *「ます」(文末語数)), g16_g50 (カタカナ $(\%) * 「 た い 」($ 文末語数)), g37_g56 (単語心像性 4 点台 (語数) *「か」(\%)),g40_g49（「な」(語数）*「ます」

(文末語数)）を選択すると, 目的変数との相関係数が 0.601 となった. g16_g50のみは符号は正で, 残り 3変数は符号が 負である。従って, カタカナの割合が低く，かつ，「な」の 語数や文末の「ます」の語数が少ない場合や, 単語心像性 4点台の語数が少なく, かつ,「か」の割合が小さい場合, または, カタカナの割合が高く,「たい」の文末語数が多い 場合は，不快性の因子得点が高くなると考元られる。

表10の例のうち，A5-4 はカタカナの割合が低く，「ます」 の割合が少なくなって㧍り，Q5 はカタカナの割合が高く, 「たい」が多い場合となっている. 両方とも単語心像性4点 台の語数,「か」の割合,「な」の語数,「ます」の文末語数 は少なくなっている。 また, 表11の例では, A4-1 はカタカ ナの割合が高く、「ます」の割合が高くなっており，Q7はカ タカナの割合が低く、「たい」が少ない場合となっている.
両方とも単語心像性 4 点台の語数，「か」の割合，「な」の語 数,「ます」の文末語数は多くなっている.

- 第3因子 (独創性)

g52_g52（「ぞ」(\%)*「ぞ」(\%)), g4_g13(文数*感動 詞 (語数) ), g58_g59（「ます」(\%) *「ない」(\%)）を選択 したところ，目的変数との相関係数が 0.618 となった，g52_ g52, g4_g13は符号が正で, g58_g59は符号が負である. 従っ て,「ぞ」の割合が高い場合や, 文数, 感動詞が多く,「ない」 や「ます」の割合が低いと, 独創性の因子得点が高くなると 考えられる。

表10の例のうち，A10-1 は「ぞ」の割合が高く，A2-1は 文数と感動詞が多い場合となっており, 両方とも「ない」 や「ます」の割合は低くなっている。また, 表11の例では, 文数と感動詞が少なく,「ます」の割合が高くなっている.

・第4因子（容易性）

g10_g64（副詞 (語数）*「ました」(語数)），g7_g29（全 角記号 (語数) *「?」の数) を選択すると, 目的変数との相 関係数が 0.638 となった，いずれの変数も符号は負である. 従って, 副詞の語数が少なく, かつ,「ました」の語数が少 ない場合や, 全角記号の数が少なく, かつ, 疑問符の数が少 
ない場合は，容易性の因子得点が高くなると考えられる，

表10の例でも, その傾向が見られる. また, 表11の例では, 全角記号や疑問符が使われている。

・第5因子（執肳性）

g4_g5 (文数*文の長さ平均 (字数)) を選択すると, 目的 変数との相関係数が 0.692 となった。符号は正であることか ら, 文数, 文の長さの平均字数が共に多ければ, 執拗性の因 子得点が高くなると考えられる。

表 10 の例は, 文章は7文あり, 文の長さは平均 46.2 文字 であり, 表 11 の例は, 文の長さは平均 34 文字と少々長いが 文章は1文のみであるので, 確かにその傾向が見られる。

・第6因子 (曖昧性)

g4_g5 (文数*文の長さ平均 (字数)) を選択すると, 目的 変数との相関係数が 0.622 となった．符号は負であることか ら, 文数, 文の長さ平均字数が少なければ, 曖昧性の因子得 点が高くなると考えられる

表 10 の例は, 文の長さは平均 34 文字であり, 文章は 1 文 のみであり, 表 11 の例は, 文の長さは平均 25.8 文字と少な いが文章は 5 文あるので，確かにその傾向が見られる。

・第7因子 (感動性)

3 個前後の変数を選択しても, 相関係数が 0.6 上回らな かった，そこで，目的変数との相関係数が相対的に大きかっ た g4_g13 (文数*感動詞 (語数)) と g23_g42 (形容詞 $(\%) *$ 「たい」(語数))を選択した.いずれの変数も符号が正である. 従って, 文数, 感動詞が多い場合や, 形容詞の割合が高く, かつ,「たい」の語数が共に多ければ, 感動性の因子得点が 高くなると考えられる.

表10の例では，文章は6文であり，感動詞が使われてい るので, その傾向が見られる，また，表 11 の例では，文章 は2文であり，形容詞が使われているが，感動詞，「たい」 は確かに使われていない

- 第8因子（努力性）

g57_g60 (「です」(\%)*「か」(文末\%)), g23_g42(形容

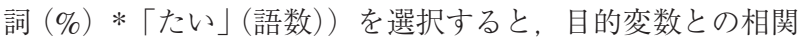
係数が 0.623 となった。いずれの変数も符号は正である. 従っ て，「です」の割合，「か」の文末に扔ける割合が共に高い場 合や，形容詞の割合が高く，かつ，「たい」の語数が多い場 合は，努力性の因子得点が高くなると考えられる。

表10の例のうち，Q7は「です」の割合や「か」の文末に おける割合が共に高くなっており，A10-4は「たい」の語数 が多くなっている。 また, 表11の例では, A1-4では形容 詞が使われているが, それ以外ではこれらの特徴量は確かに 使われていない.

・第9因子 (熱烈性) g42_g55 (「たい」(語数) *「ね」(\%)),g52_g52（「ぞ」(\%) *「ぞ」(\%)), g43_g59（「ない」(語数)*「ない」(\%))を選 択すると, 目的変数との相関係数が 0.600 となった. 3 変数 とも符号は正である。従って，「ぞ」の割合が高い場合や， 「たい」や「ね」の割合が高い場合，「ない」が多い場合は, 熱烈性の因子得点が高くなると考えられる。
表10の例のうち, A10-4は「たい」や「ね」の割合が高く， 「ない」が多くなっており, A10-1は「ぞ」の割合が高くなっ ている. また, 表11の例では, これらの特徵量は確かに使 われていない.

以上より，全ての因子において，代表特徵量は因子得点の 推定に寄与していることがわかり，推定が妥当であると考え られる。

\section{7. まとめ}

本論文では, 質問者と回答者の相性の判定をめざして, 文章の因子得点の推定を行った。ここでは，構文情報，単語 心像性と文末表現を文章の特徵量として使用して，質問回答 文の因子得点の推定を試みた。その結果，全ての因子におい て精度良く推定できることを示した。また，文末表現だけで なく，文章全体の文体や内容にも着目することにより，文章 の因子得点の推定精度を向上できることを示した。さらに， 各因子の推定において重要な特徵量を用いて推定の妥当性を 確認した.

今後は，今回得られた重回帰式を用いて，まだ求まってい ない質問回答文の因子得点を求めていき,「ベストアンサー」 の推定を行う予定である。ただし, 重回帰式を使用する際, 重回帰式を求めるために使用した 60 個の質問回答文の特徵 量と，その他の質問回答文の特徴量の統計的な性質に差が あってはならないので, これらの特徵量に有意差がないこと を確かめながら因子得点の推定を行う必要があると考えてい る.また, すでに特徵量に使用している単語心像性以外にも, 単語親密度, 表記妥当性, 単語複雑度など [13], 文章の印 象に影響すると考えられる特徽量が知られていることから， 今後, これらを特徵量に加えた上で，因子得点の推定精度の さらなる向上を図る予定である。

\section{謝 辞}

本研究は一部, 科研費 (21500091) の助成を受けて行われ たものである。また，実装・評価に際し，大学共同利用機関 法人国立情報学研究所から提供を受けた, Yahoo! 知恵袋の データを利用している。ここに記して謝意を示す。

\section{参 考 文 献}

［1］Yahoo! 知恵袋, http://chiebukuro.yahoo.co.jp/

［2］横山友也，宝珍輝尚，野宮浩揮，佐藤哲司：質問回答サイ トの質問文と回答文の印象評価とベストアンサーの推定, 日本感性工学会論文誌, Vol.10, No.2, pp.221-230, 2011

［3］横山友也，宝珍輝尚，野宮浩揮，佐藤哲司：文章の特徵量 を用いた質問回答文の因子得点の推定精度の向上，日本感 性工学会関西支部大会 2011 . 
４4］西原陽子, 松村真宏, 谷内田正彦：Q\&Aコミュニティで の質疑応問パターンの理解, 第 22 回人工知能学会全国大 会, 1H2-7, 2008.

[5] Blooma, M.J. and Chua, A.Y.K. and Goh, D.H.L.: A Predictive Framework for Retrieving the Best Answer, Proc. of 2008 ACM Symposium on Applied Computing (SAC08), pp.1107-1111, 2008.

[6] Agichtein, E., Castillo, C., Donato, D., Gionis, A. and Mishne, G.: Finding High-Quality Content in Social Media, Proc. of the Int' 1 Conf. on Web Search and Web Data Mining (WSDM08), pp.183-194, 2008.

[7] Wang, X. J., Tu, X., Feng, D. and Zhang, L.: Ranking Community Answers by Modeling Question-Answer Relationships via Analogical Reasoning, Proc. of 32nd Int'l ACM SIGIR Conf., pp.179-186, 2009.

[8] Kim. S., Oh, J. S. and Oh, S.: Best-Answer Selection Criteria in a Social Q\&A site from the User-Oriented Relevance Perspective, Proc. of American Society for Information Science and Technology (ASIS\&T) 2007 Annual Meeting, 2007.

[9] Adamic, L. A., Zhang, J., Bakshy, E. and Ackerman, M. S.:Knowledge Sharing and Yahoo Answers: Everyone Knows Something, Proc. of 17th Int'l Conf. on World Wide Web (WWW2008), 2008.

[10] Jurczyk, P. and Agichtein, E.: Discovering Authorities in Question Answer Communities by Using Link Analysis, Proc. of 16th ACM Conf. on Inf. and Know. Management (CIKM2007), pp.919-922, 2007.

[11] Hovy, E., Gerber, L., Hermjakob, U., Junk, M. and Lin, C.Y.: Question Answering in Webclopedia, Proc. of 9th Text Retrieval Conf., pp.655-664, 2000.

[12] 熊本忠彦：新聞記事を対象とする印象空間の構築，第 12 回 Webインテリジェンスとインタラクション研究，WI2-20075, 2008.

[13] 佐久間尚子, 伊集院睦雄, 伏見貴夫, 辰巳格, 田中正之, 天野成昭, 近藤公久：単語心像性(1), NTTデータベース シリーズ日本語の語彙特性 第3期 (第8巻), (社) 三省堂, 2005.

[14]田中豊, 脇本和昌: 多変量統計解析法, pp.190-191, (社) 現 代数学社, 1983.

[15] 朝野熙彦：入門多変量解析の実際 第2 版, p.64, (社) 講談 社, 2000 .

[16] Text Seerマニュアル, http://www.valdes.titech.ac.jp/ t_kawa/ts/manual.htm
［17］菅民郎，初心者がらくらく読める多変量解析の実践 上, pp.42-45, (社) 現代数学社, 1993.

[18] NTTデータベースシリーズ, http://www.kecl.ntt.co.jp/mtg/goitokusei/

[19］重回帰分析（ステップワイズ変数選択）, http://aoki2.si.gunma-u.ac.jp/R/sreg.html

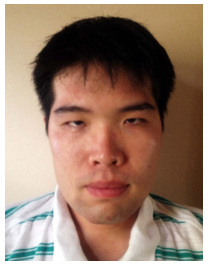

横山 友也（学生会員）

2012年 京都工芸繊維大学大学院博士前期課 程修了. 現在京都工芸繊維大学大学院博士後 期課程在学中。この間, マルチメディアデー夕 工学, 感性工学に関する研究に従事. 日本感 性工学会学生会員.

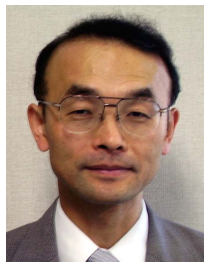

\section{宝珍 輝尚（正会員）}

1984年 名古屋工業大学大学院修士課程修了. 同年, 日本電信電話公社入社. NTT電気通 信研究所, 福井大学, 大阪府立大学を経て, 2006 年より京都工芸繊維大学大学院工芸科 学研究科教授. 博士 (工学). 感性マルチメディ アデータ検索, マルチメディアデータベースシステムの研究 に従事. 日本感性工学会, 電子情報通信学会, 情報処理学会, 日本データベース学会, 日本情報考古学会, IEEE, ACM 各会員.

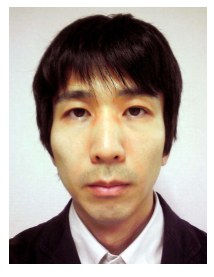

野宮 浩揮 (非会員)

2008 年 神戸大学大学院自然科学研究科修了. 同年より京都工芸繊維大学工芸科学研究科助 教. 工学博士. この間, 画像認識, 表情認識, マルチメディアデータ工学, 機械学習等に関 する研究に従事. 情報処理学会, 人工知能学 会, 日本データベース学会各会員.

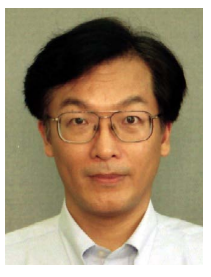

佐藤 哲司 (非会員)

1980 年 山梨大学工学部電子工学科卒業. 同年日本電信電話公社 (NTT) 武蔵野電気通 信研究所に入所. 1994年工学博士 (大阪大学) 取得. NTTコミュニケーション科学基礎研 究所を経て，2007年4月より現職。情報アク セス技術，社会インタラクションに関する研究に従事．電子情 報通信学会, 情報処理学会各会員. 